\title{
A Research on Solar Greenhouse Dryer
}

\author{
Kanika Jindal, Jitendra Kumar
}

\begin{abstract}
For taking away the humidity material drying procedure is achieved. Evolution of roof variety, particularly, solar cycle drier kayak drier solar tunnel drier, and greenhouse sprays length research workers have learned greenhouse drier. Inside this newspaper drier below convection variety and convection sort have been all studied. Greenhouse drier provides rather large excellent product compared to sun drying that is open plus the harvest declines are reduced by it. It's been discovered that the use of rainwater drier below convection lessens moisture material in addition to drying speed is rapid and comparative humidity is significantly less than convection manner.
\end{abstract}

\section{INTRODUCTION}

Greenhouse drier is a enclosed construction with translucent roofs and walls, madeup of glass, polyethylene picture etc.. Greenhouse's occurrence specified at which the item is put in-trays getting the radiations throughout dampness and the cap will be taken out by natural convection or convection. The item quality enhances and also lessens the time interval [inch ]. Taking arrangement greenhouse drier is categorized to two sorts which are do me roof and form form. Target and benefit of the dome and roofing style greenhouse drier are to make the most of use of solar power and also would be your mixing of atmosphere within the drier. To the grounds of heat transport, it has two Type-S particularly greenhouse drier underneath inactive modes (normal convection) and rainwater drier under busy manner (driven convection) [two ]. Greenhouse dryers' use is to enhance the product's caliber, to stop the illness by microorganisms insects and bacteria, and also decrease of drying period interval [3].Greenhouse sprays are assembled of a basic theory they will have a stiff load- bearing framework that's set at particular intervals rather than repainting underneath the heaps acting to these and also a translucent covering material set them that makes it possible for short-wave solar power to input plus also can be somewhat clear into the lengthy wave radiation causing some greenhouse result. Style and design of rainwater must rely which eases controlled atmosphere. Orientations of all green houses are to negotiate for breeze management, permission of site and sort of temperature controller and prevent falling of darkness onto the green houses. It's reasoned in the plan of both the greenhouse, orientation and the form of the greenhouse play an crucial purpose [4]. Greenhouse acquiring contours that the following such as terrace paraboloid altered Quonset arch gain even length. Cheap, simple structure, right for a basic device to use. Drying temperature is low and also permit

Revised Version Manuscript Received on 16 September, 2019.

Kanika Jindal, Electronics and communication Engineering, Noida Institute of Engineering and Technology, India E-Mail: research.paper@niet.co.in

Jitendra Kumar, Mechanical Engineering, Noida Institute of Engineering and Technology, India E- Mail: research.paper@niet.co.in experience of the cloth of the sun. That the absolute radiation power usage speed is utilized for humidity evaporation substances is accepted by Solar-energy drying lost for the air [5].

\section{LITERATURE REVIEW}

Saravia and also conform researched the efficacy of double room greenhouse dryer and forced single. Results revealed that room inflatable drier is 87 percent more productive than room for equal location. A fresh lowcost designing tunnel-type greenhouse drier has been assembled and analyzed [6].Wang et al. offered experimental investigation of atmosphere rate supply within a naturally ventilated greenhouse. The effect revealed as a result of 0.837 of this regression slope of the determined atmosphere rate was significantly lower compared to quantified worth. It reasoned that the average worthiness of atmosphere speed in green houses is to enjoy an element for calculating heating transports amongst greenhouse parts along with air [7].Condori and Saravia offered. It reasoned by thinking about the greenhouse dryer as being a solar collector, even an analytical terminal connection has been based because to that a marked addition of approximately 160 percent with regard to just one room dryer, whereas the progress is currently still about 40 percent in comparison with all the dual room dryer [8]. Farhat et al. exhibited drying version with a banana at a naturally-occurring saltwater. The effect revealed the variety of item drinking water loss that is often expressed as a role of venting speed or triggered air imparted power and air speed and product temperature by means of a greenhouse cap. It reasoned the process that was drying permit the manipulation of Poly Ethylene green houses at the summertime if used [9].Jain and also Tiwari learned of mass transport coefficient and achieved moisture removing speed in peas and cabbage to get greenhouse drying and sun. It reasoned in an organic manner, the convective mass transport coefficient was to reduce within the rainwater drying compared to receptive sun-drying and also at the first phase of drying, and its own worth was dipped below driven manner in rainwater drying compared to ordinary convection [10].Tiwari et al. generated an endeavor to take a look at the convective mass transport coefficient from a regression investigation throughout jaggery drying at the roofing type much length greenhouse under forced and natural convection manner. It had been revealed the whole drying of jaggery underneath forced convection as faster than beneath standard convection because expectable and convective mass transport coefficient in forced convection was significantly greater compared to

Published By:

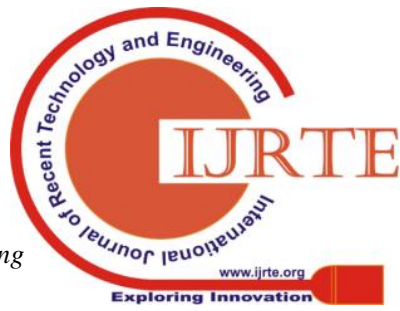


organic convection modes [11].Jain and also Tiwari offered mathematical design to look into the results of rainwater on plants drying (Cabbage and Peas) underneath forced and natural convection as well as also to get receptive sun-drying (normal convection) [12].Jain made a model to research the operation of the period greenhouse with bed for drying out blossoms saline storage has been completed outside. It had been noticed the harvest moisture content and speed declines with all this day's period.

\section{RESULTS \& DISCUSSIONS}

This version is helpful for predicting the harvest temperature, humidity content and drying speed of harvest and also thus for estimating the update of harvest drying utilizing such a greenhouse [13]. Koyuncu researched about the operation upgrade of greenhouse type sprays. It reasoned that these sorts of dryers are 25 times better and has been far significant grade compared to air conditioners that were receptive as it dried an assortment of services and products and also to avoid [14]. Jana along with Chaichoet et al. researched the operation of the PV-ventilated rainwater drier for drying out carrots. The outcomes demonstrated sun drying demanded 5 weeks of drying period as well as that 50 kilograms of peanuts with first moisture content of 70 per cent may be dried at 3 times. It reasoned, the services and products of high quality have been obtained [15].Kumar and also Tiwari learned the impact of mass on heat transport coefficient throughout onion flakes. It reasoned there clearly is $30-135 \%$ boost in convective heat transport whilst the bulk of onion sprouts has been raised from 300 to 900 grams for unique ways of drying plus it is based upon the manner of drying and also around the mass of cereal into become dried [16].Kumar and also Tiwari offered experimental identification along with renewable modeling of rainwater drying procedure for jaggery underneath forced convection manner. It reasoned the thermal version had been first prescribed with all variety and all the discoveries of air changes per hour, relative humidity bulk ended up parameters for drying out of modes [17].Tiwari et al. analyzed subconsciously, greenhouse drying (normal convection) of all both prawn. It called the convective heat transport coefficients because a function of dampness material of prawn and thanks to dimension and original moisture content of prawn, principles of convective heat transport coefficient diverged drastically with dimension and also the kind of materials [18].Das and also Tiwari conducted convective heat transfer coefficient throughout rainwater fish pruning to get prawn underneath forced convection style. It reasoned that if of convection drying, the moisture eliminated as fast and significantly more than the convection drying [1 9]. Shukla et al. conducted an experimental analysis from a cascade rainwater to observe that the consequence of an internal combustion drape in a underfloor heating program [20]. Arora and also set failed to progress in greenhouse drying with west wall manifestation under forced and pure convection style. To the grounds of why results, it reasoned that interior rainwater drier, brilliantly likely reflective northern west wall may considerably boost the entire atomic power that's attendant on the harvest also it might likewise boost both atmosphere and harvest temperature of it underneath pure and driven convection manner of drying out of 10 am to two pm [2-1]. Jana et al. introduced an experimental operation of the PV- coated solar dryer for drying of sausage and banana longan. Its effect revealed that these services and merchandise dried inside this really are very reductions in period and dehydrated item or service compared to sun drying [2-2]. Ayyappan along with Mayilsamy were made solar tube drier to try its demonstration. It reasoned for creating premium excellent copra, there has been an all all-natural solar tube drier right to its farmers [2 3]. Nayak et al. demonstrated drying and testing of mint with the way of a hybrid photovoltaic-thermal (PVT) - established greenhouse drier. The effect revealed it's burning efficacy was computed as 34.2percent and web extenuation on the span was computed as 140.97 heaps and dehydrated services and products with raised shelf life span and also complete excess body fat, carbohydrates, protein, ash, crude fiber and chlorophyll contents have been higher from dehydrated samples compared to samples that were fresh. It reasoned it had been employed for natural uses [2 4]. Boonyasri et al. examined that the operation and also financial test of greenhouse drier for pork drying. It reasoned that the humidity content has been decreased from D B at 320 minutes in the opinion of greenhouse purification required just 260 minutes [25].Kashani and also Saladin offered examination of the greenhouse tube dryer. The effect revealed that SGTD lessens copra's dampness from 52.2 percent to 8 percent at $55 \mathrm{~h}$ under complete loading requirements. To the grounds of final outcomes it's reasoned this type of dryer employed in rural places without power grids and projected meed phases with the drier for copra are approximately 2.3 years now [26].Kumar et al. researched the convective heat transfer coefficient of both khoa in either greenhouse and also open sun-drying for forced and all-natural convection manners. It reasoned that heat transport coefficient within the greenhouse below manner had been less compared to different manners also it absolutely had been high as it reduces as of drying up-grades to this day, your evening [27]. Ghosh and ganguly offered venting and cooling technologies that were employed to green houses. It reasoned by pinpointing a few areas that more analysis should be kept [28]. Balachandran and akinjiola revealed a tech to greenhouse drier such as post- crop preservation issues in growing states. It reasoned that the inflatable dryer with the product caliber of its own layout and designs weren't necessarily feasible or economical [29]. Janjai learned dissemination and that the evolution of farmers dryer for meals items businesses that were dried. The effect demonstrated that evaluated revival durations of rainwater kind solar drier for tomato is all about 0.65 years now [30]. Jana et al. gave attention appraisal of the greenhouse gas dryer of longan fruits drying. It had been noticed that massaging atmosphere temperatures varied thanks to that decent selection and also decent high quality dried longan veggies were got [3-1].Anil et al. offered an experimental investigation of greenhouse drier under no load problems. It had been reasoned that 
massaging speed of convection is significantly efficient compared to convection from $3-1 \%$ due of humidity because of convection is significantly less than

this of convection manner [32]. Kumar introduced magnitude of khoa's impact throughout convection style on mass and heat transport coefficients. The outcomes demonstrated the mass and heat transport coefficients reduction because of improve the size of their show bits [3 3]. Prakash and Kumar produced an endeavor for its prediction of mass-produced tagger drying within the all-natural convection greenhouse drier with using synthetic neural network (ANN). It had been reasoned that the ANN version became an increasingly helpful instrument for its forecast of hourly mass [34]. Rai et al. has been presented an experimental analysis of massaging from the driven convection manner. It had been observed that the ordinary heat transport coefficient is before its convection rainwater drying compared to the sun-drying manner [35].Tanwanichkul et al. suggested thermal modeling of sandwich water drying procedure to get plastic sheets beneath forced convection. This ends demonstrated the humidity material may diminish from 36.4percent to 2.8percent in over two times of their plastic sheets [36].Kumar conducted an experimental analysis of vermicelli drying underneath organic convection manner. It had been detected over times, similar to worth of heat transport coefficients had been received to get dried up such like sample [3-7]. Vermicelli drying faculties within the height inflatable drier was offered by nidhi. It reasoned that massaging speed and humidity content over the dry basis (percent) is seen to function as decreasing determined by rising drying period [38].The convective and evaporative heat transport coefficients to get papad under pressured convection rainwater drying manner were quantified [3 9]. Results revealed the monsoon seasons were somewhat also at and also inconsistent drying requirements that were weaker. Drying in manner was indicated reassuring compared to manner owing to restraining humidity via an exhaust fan. For drying out of cocoa beans at the greenhouse dryer, A modeling has been made [40]. It has been noted, the rainwater tech boosts the caliber of the item and lessens the time interval of time.

\section{CONCLUSION}

Following conclusion is drawn:Drying speed is speedier below convection than convection style.Style is a lot significantly more than sun drying. Values of heat transport coefficient various with all moisture material and exactly the dimensions of the item. The use of likely expression north wall from greenhouse drying may increase the engine power.PV- solar drier provides an Exact Large quality reduces drying period and dried merchandise Air sun.For farmers convection solar tube drier is much convenient.Greenhouse drying lessens moisture material at a time that is significantly much less.Solar greenhouse tube dryer might be utilized in rural locations.Humidity underneath forced convection is poor to ordinary convection style.Greenhouse kind sprays are obviously higher grade and much better than sun barrels.

\section{REFERENCE}

1. V. R. Maske and V. P. Dhulap, "Development of Handy Prototype Gas Sensors Kit for Monitoring of Ambient Green House Gases from Solid Waste Disposal Sites of Solapur City," in EMERGING TECHNOLOGIES: MICRO TO NANO (ETMN-2017), 2018, vol. 1989.

I. N. K. Wardana, P. I. Ciptayani, and I. W. A. Suranata, "Sub-1GHz wireless sensing and control instruments for green house farming system," in 2ND INTERNATIONAL JOINT CONFERENCE ON SCIENCE AND TECHNOLOGY (IJCST) 2017, 2018, vol. 953.

2. R. Trojanek, M. Gluszak, and J. Tanas, "THE EFFECT OF URBAN GREEN SPACES ON HOUSE PRICES IN WARSAW," Int. J. Strateg. Prop. Manag., vol. 22, no. 5, pp. 358-371, 2018.

3. D. Rahmawati, M. Ulum, and H. Setiawan, "Design of Android Base Fuzzy Wireles SensorNetwork for mini Smart Green House," in 2ND INTERNATIONAL CONFERENCE ON STATISTICS, MATHEMATICS, TEACHING, AND RESEARCH 2017, 2018, vol. 1028.

4. H. Shehadeh, W. Mardini, M. B. Yassein, D. H. Allah, and W. B. Yaseen, "'Hop Count\{'"\} Dynamic Double Trickle Timer Algorithm Use Case: Data Aggregation in Smart Green House," in ICFNDS'18: PROCEEDINGS OF THE 2ND INTERNATIONAL CONFERENCE ON FUTURE NETWORKS AND DISTRIBUTED SYSTEMS, 2018.

5. K. Shelton and W. Fulton, "Fun for all ages Weaving greenspace, transportation, and housing together in the intergenerational city," in MILLENNIAL CITY: TRENDS, IMPLICATIONS, AND PROSPECTS FOR URBAN PLANNING AND POLICY, Moos, M and Pfeiffer, D and Vinodrai, T, Ed. 2018, pp. 253-265.

6. G. L. Fernando, M. H. Liyanage, and G. N. Samarasekara, "Energy and Environmental Implications of Green House Gas Mitigation Policies in the Transport Sector of Sri Lanka," in PROCEEDINGS OF THE 2018 INTERNATIONAL CONFERENCE AND UTILITY EXHIBITION ON GREEN ENERGY FOR SUSTAINABLE DEVELOPMENT (ICUE 2018), 2018.

7. X.-L. Fu, "Research on the Architectural Design Method of Green Materials Related to Teahouse Space: Taking the Bamboo House for example," in 2018 INTERNATIONAL CONFERENCE OF GREEN BUILDINGS AND ENVIRONMENTAL MANAGEMENT (GBEM 2018), 2018, vol. 186.

8. B. Preller, "Luxembourg: A Policy-Led Approach Caught Between Green Growth and Affordable Housing," in GREEN BUILDING TRANSITIONS: REGIONAL TRAJECTORIES OF INNOVATION IN EUROPE, CANADA AND AUSTRALIA, 2018, pp. 159-188.

9. E. Fesselmeyer, "The value of green certification in the Singapore housing market," Econ. Lett., vol. 163, pp. 36-39, Feb. 2018.

10. B. Cohen, "Enigmas of the Third Space: Mingus and Varese at Greenwich House, 1957," J. Am. Musicol. Soc., vol. 71, no. 1, pp. 155-211, 2018.

11. Y. Zhang and R. Dong, "Impacts of Street-Visible Greenery on Housing Prices: Evidence from a Hedonic Price Model and a Massive Street View Image Dataset in Beijing," ISPRS Int. J. GEO-INFORMATION, vol. 7, no. 3, Mar. 2018.

12. J. B. Akom, A.-M. Sadick, M. H. Issa, S. Rashwan, and M. Duhoux, "THE INDOOR ENVIRONMENTAL QUALITY PERFORMANCE OF GREEN LOW-INCOME SINGLE-FAMILY HOUSING," J. GREEN Build., vol. 13, no. 2, pp. 98-120, 2018.

13. L. Zhang, L. Chen, Z. Wu, S. Zhang, and H. Song, "Investigating Young Consumers' Purchasing Intention of Green Housing in China," SUSTAINABILITY, vol. 10, no. 4, Apr. 2018.

14. J.-H. Huh, "Implementation of lightweight intrusion detection model for security of smart green house and vertical farm," Int. J. Distrib. Sens. NETWORKS, vol. 14, no. 4, Apr. 2018.

15. R. Rothstein, "HIGH-RISERS Cabrini-Green and the Fate of American Public Housing," NEW YORK TIMES B. Rev., vol. 123, no. 15, p. 21, Apr. 2018.

A. R. Gill, K. K. Viswanathan, and S. Hassan, "A test of environmental Kuznets curve (EKC) for carbon emission and potential of renewable energy to reduce green house gases (GHG) in Malaysia," Environ. Dev. Sustain., vol. 20, no. 3, pp. 1103-1114, Jun. 2018.

16. L. Zhang, L. Chen, Z. Wu, H. Xue, and W. Dong, "Key Factors Affecting Informed Consumers' Willingness to Pay for Green Housing: A Case Study of Jinan, China," SUSTAINABILITY, vol. 10, no. 6, Jun. 2018. 
17. O. Tahvonen and M. Airaksinen, "Low-density housing in sustainable urban planning - Scaling down to private gardens by using the green infrastructure concept," Land use policy, vol. 75, pp. 478-485, Jun. 2018.

18. F. Fuerst and G. Warren-Myers, "Does voluntary disclosure create a green lemon problem? Energy-efficiency ratings and house prices," ENERGY Econ., vol. 74, pp. 1-12, Aug. 2018.

19. Y. Mei, X. Zhao, L. Lin, and L. Gao, "Capitalization of Urban Green Vegetation in a Housing Market with Poor Environmental Quality: Evidence from Beijing," J. URBAN Plan. Dev., vol. 144, no. 3, Sep. 2018.

20. G. H. Park and S. M. Kwon, "The ameliorated trade-off between commuting efficiency and jobs-housing balance in a green-belted city: Lessons from Seoul," Socioecon. Plann. Sci., vol. 63, pp. 47-59, Sep. 2018.

21. H.-C. Park and M. K. Patel, "Naphtha storage fraction and green house gas emissions in the Korean petrochemical industry," ENERGY Environ., vol. 29, no. 6, pp. 919-937, Sep. 2018.

22. [Anonymous], "Students' precast concrete solar house a green marvel,” PCI J., pp. 16-17, 2018.

A. Nowoswiat, J. Slusarek, R. Zuchowski, and B. Pudelko, "The Impact of Noise in the Environment on the Acoustic Assessment of Green Houses," Int. J. Acoust. Vib., vol. 23, no. 3, pp. 392-401, Sep. 2018.

23. G. Gel and E. Satiroglu, "DETERMINATION OF OPEN GREEN SPACE USAGE IN HOUSING ESTATES,” OPEN HOUSE Int., vol. 43, no. 3, pp. 59-68, Sep. 2018.

24. R. de Graaf, "High-Risers: Cabrini-Green and the Fate of American Public Housing,” New York Rev. Books, vol. 65, no. 14, pp. 67-70, Sep. 2018.

25. L. Zhang, J. Wu, and H. Liu, "Policies to enhance the drivers of green housing development in China," Energy Policy, vol. 121, pp. 225-235, Oct. 2018.

A. Rigolon and J. Nemeth, "'We're not in the business of housing: \{’\} Environmental gentrification and the nonprofitization of green infrastructure projects," CITIES, vol. 81, pp. 71-80, Nov. 2018.

B. L. Simon, "Sense and sensibility: Dual knowledge bases of Greenwich House, NYC, 1902-1920," Qual. Soc. Work, vol. 17, no. 6, pp. 814-831, Nov. 2018.

26. S. Geng and L. Lin, "The extensible evaluation framework of urban green house gas emission reduction responsibility: A case of Shandong province in China," ENERGY, vol. 162, pp. 171-184, Nov. 2018.

27. T. B. Hammed, S. O. Wandiga, Y. Mulugetta, and M. K. C. Sridhar, "Improving knowledge and practices of mitigating green house gas emission through waste recycling in a community, Ibadan, Nigeria," WASTE Manag., vol. 81, pp. 22-32, Nov. 2018.

28. X. (Jason) Cao and S. Lou, "When and How Much Did the Green Line LRT Increase Single-Family Housing Values in St. Paul, Minnesota?," J. Plan. Educ. Res., vol. 38, no. 4, pp. 427-436, Dec. 2018.

29. K. Laszlo, L. Morin, and C. L. Veeder, "PREDICTORS OF PAIR HOUSING SUCCESS VARY IN CAPTIVE ST. KITTS AFRICAN GREEN MONKEYS (CHLOROCEBUS SABAEUS) VERSUS CAPTIVE TANZANIAN AFRICAN GREEN MONKEYS (CHLOROCEBUS PYGERYTHRUS),” Am. J. Primatol., vol. 80, no. 1, SI, Dec. 2018.

30. G. Choi, S. Lee, H. Kim, and E. Y. Seong, "Critical junctures and path dependence in urban planning and housing policy: A review of greenbelts and New Towns in Korea's Seoul metropolitan area," Land use policy, vol. 80, pp. 195-204, Jan. 2019.

31. N. M. C. Ha, T. H. Nguyen, S.-L. Wang, and A. D. Nguyen, "Preparation of NPK nanofertilizer based on chitosan nanoparticles and its effect on biophysical characteristics and growth of coffee in green house," Res. Chem. Intermed., vol. 45, no. 1, SI, pp. 51-63, Jan. 2019.

32. R. Yilmaz, C. Bayrac, A. Basman, and H. Koksel, "Development of SYBR green-based real time PCR assays for detection and quantification of adulteration in wheat-based composite breads and their in-house validation," J. Cereal Sci., vol. 85, pp. 91-97, Jan. 2019.

33. E. Jacobs, J. Wilson, S. L. Dixon, and J. Breysse, "Moving Into Green Healthy Housing,” ASHRAE J., vol. 61, no. 1, pp. 66-69, Jan. 2019.

A. Banik, G. K. Dash, P. Swain, U. Kumar, S. K. Mukhopadhyay, and T. K. Dangar, "Application of rice (Oryza sativa L.) root endophytic diazotrophic Azotobacter sp. strain Avi2 (MCC 3432) can increase rice yield under green house and field condition," Microbiol. Res., vol. 219, pp. 56-65, 2019.

34. Q. Li, R. Long, H. Chen, F. Chen, and X. Cheng, "Chinese urban resident willingness to pay for green housing based on double-entry mental accounting theory," Nat. HAZARDS, vol. 95, no. 1-2, SI, pp. 129-153, Jan. 2019. 